\title{
A EFETIVAÇÃO DAS FUNÇÕES SOCIAIS DA CIDADE POR INTERMÉDIO DA CIDADANIA PARA A GESTÃO DEMOCRÁTICA NAS CIDADES
}

\section{EFFECTIVENESS OF CITY'S SOCIAL FUNCTIONS THROUGH CITIZENSHIP FOR DEMOCRATIC MANAGEMENT IN CITIES}

Sinara Camera ${ }^{1}$

Renata Maciel $^{2}$

\section{RESUMO}

O artigo analisa a gestão democrática da cidade como forma de efetivação da cidadania e do desenvolvimento das funções sociais da cidade. O problema apresenta o exercício da cidadania por parte dos citadinos na gestão democrática como possibilidade de efetivação das funções sociais da cidade. Questiona-se, ainda, se a maior participação dos citadinos na tomada de decisões é uma possibilidade de diminuição das desigualdades sociais e promoção dos direitos humanos. O objetivo é analisar a importância da cidadania para o desenvolvimento das cidades, no que tange ao cumprimento de suas funções sociais. O método de abordagem é o hipotético-dedutivo, com pesquisa teórica e tratamento de dados qualitativo. Apresenta como resultado que, por meio da gestão democrática das cidades, é possível a avaliação de interesses coletivos com vistas a reduzir a desigualdade social, o que faz com que as cidades se tornem o local ideal para que os direitos humanos sejam efetivados. Conclui-se que a gestão democrática deve buscar um desenvolvimento que vise combater as desigualdades, o desenvolvimento sustentável por meio do planejamento

\footnotetext{
${ }^{1}$ Doutora em Direito Público pela Universidade do Rio dos Sinos (UNISINOS), com período de doutoramento na Universidade de Sevilla (US - Espanha), realizado com bolsa PDSE- CAPES, Processo no 18627/12-9. Mestre em Integração Latino-Americana pela Universidade Federal de Santa Maria (MILA/UFSM). Graduada em Direito pelo Instituto de Ensino Superior de Santo Ângelo (IESA). Professora do Curso de Direito das Faculdades Integradas Machado de Assis (FEMA) nas áreas de Teoria do Estado, Direitos Humanos, Direito Internacional Público e Direito Comunitário e da Integração. Pesquisadora nas áreas do Direito Internacional dos Direitos Humanos, da Teoria do Estado e da Cooperação Internacional. Fundação Educacional Machado de Assis, FEMA, Rio Grande do Sul. Brasil. E-mail: sinaracamera@gmail.com

2 Doutoranda em Diversidade Cultural e Inclusão Social pela Universidade FEEVALE, com bolsa da CAPES. Mestre em Direitos Humanos pela Universidade Regional do Noroeste do Estado do Rio Grande do Sul UNIJUÍ, com bolsa da FAPERGS. Especialista em Direito Administrativo e Especialista em Direito Previdenciário pela Universidade Anhanguera - UNIDERP (2013). Graduada em Direito pela Universidade Regional do Noroeste do Estado do Rio Grande do Sul - UNIJUÍ (2010). Professora do curso de Direito da Fundação Educacional Machado de Assis - FEMA. Advogada. Universidade FEEVALE, Rio Grande do Sul. Brasil. E-mail: advogada.rmaciel@gmail.com
} 
urbano mais humano, menos excludente, objetivando a vida digna com qualidade para a maior parte da população, com o cumprimento das funções sociais da cidade.

Palavras-chave: Direito à Cidade. Direitos Humanos. Cidadania. Gestão Democrática das Cidades. Funções Sociais da Cidade.

\section{ABSTRACT}

The article analyzes the democratic management of the city as a form of effective citizenship and the development of their social functions. The problem presents the exercise of citizenship on the part of city dwellers in democratic management as a possibility of effecting in their social functions. It is also questioned whether the greater participation of citizens in decision-making is a possibility of reducing social inequalities and promoting human rights. The objective is to analyze the importance of citizenship for the development of cities, with respect to the fulfillment of their social functions. The approach method is the hypothetical-deductive, with theoretical research and qualitative data treatment. As a result, through the democratic management of cities, it is possible to evaluate collective interests with a view to reducing social inequality, which makes cities the ideal place for human rights to be realized. It is concluded that democratic management should seek a development aimed at combating inequalities, sustainable development through more humane, less exclusionary urban planning, aiming at decent life with quality for the majority of the population, with the fulfillment of social functions of the city.

Keywords: Right to the City. Human rights. Citizenship. Democratic Management of Cities. Social functions of the City.

\section{INTRODUÇÃO}

A urbanização brasileira ocorreu sem qualquer planejamento urbano adequado e sem a implementação de políticas públicas garantidoras de direitos fundamentais da nova população urbana que se formou. Consequentemente, as cidades brasileiras cresceram sem a infraestrutura mínima, uma vez que a urbe não foi reconhecida como obra coletiva. Em decorrência de tais fatores, a vida urbana e cidadania se afastam.

Nesse sentido, Lefebvre (2001), destaca que a urbanização brasileira corresponde ao não compartilhamento da urbe, a sua não aceitação cultural e política como obra coletiva, o que 
ocasionou uma relação conflituosa e, portanto, desencadeou um afastamento histórico entre vida urbana e cidadania. Portanto, as cidades brasileiras passaram a ser marcadas por precariedades em sua infraestrutura e pela ausência dos cidadãos nas decisões que lhes dizem respeito, o que resultou na exclusão destes inclusive no que diz respeito ao acesso a serviços básicos indispensáveis ao bemestar coletivo. Nesse sentido, reputa-se expressiva a análise da temática, visando fomentar as discussões acerca de como a gestão democrática das cidades pode contribuir para a efetivação dos direitos humanos.

Em vista de tais acontecimentos, o presente artigo destina-se a estudar a temática da gestão democrática da cidade como forma de concretização dos direitos humanos no âmbito urbano. Para tanto, apresenta como problema norteador o seguinte questionamento: o exercício da cidadania por parte dos citadinos é suficiente na gestão democrática para a efetivação das funções da cidade? E, caso positivo, se a maior participação dos citadinos é capaz de diminuir as disparidades sociais e promover os direitos humanos?

A hipótese a ser trabalhada destina-se a destacar a importância da gestão democrática da cidade como forma de reduzir as desigualdades sociais e promover os direitos humanos, uma vez que tal instituto emerge na ordem jurídica brasileira com o objetivo de que as cidades cumpram com sua função social e tornem-se justas, solidárias e democráticas, por meio da participação da população e de associações representativas dos vários segmentos da comunidade na formulação, execução e acompanhamento de planos, programas e projetos de desenvolvimento urbano que encontram respaldo legal na Constituição Federal de 1988 e na Lei 10.257/2001 (Estatuto da Cidade).

Para responder ao questionamento e confirmar ou refutar a hipótese, buscou-se, como objetivo geral, abordar a gestão democrática das cidades como principal forma de participação dos citadinos no planejamento urbano, e de materialização do exercício da cidadania, uma vez que a participação da população das cidades é essencial para o mapeamento da realidade social de cada local, e para garantir maiores possibilidades de realizar políticas eficazes no combate aos conflitos. No aspecto jurídico-legal essa participação encontra-se prevista tanto na Constituição Federal, em seu artigo 182, quanto no artigo 43, da Lei 10.257/2001 (Estatuto da Cidade).

No tocante à metodologia, a pesquisa pode ser caracterizada como teórica, uma vez que desenvolve a temática delimitada por meio de documentação indireta, bibliográfica, em livros, teses e artigos científicos; e documental, em documentos legislativos. O tratamento de dados será de forma qualitativa, baseado na organização e na análise das informações. Quanto ao método de abordagem, utilizar-se-á o hipotético-dedutivo, pois a pesquisa se dá a partir de um problema, oferecendo na hipótese uma possível solução que depois será criticada, provada ou eliminada. 
Para a sistematização da análise, o artigo foi dividido em três seções. Verifica-se em um primeiro momento as funções sociais da cidade no século XXI como forma de efetivação dos direitos humanos. A seguir, analisa-se a ligação existente entre a gestão democrática das cidades e as funções sociais. Por fim, destaca-se a importância da gestão democrática para a redução das desigualdades sociais e promoção dos Direitos Humanos.

\section{AS FUNÇÕES DA CIDADE NO SÉCULO XXI E A OBSERVÂNCIA DOS DIREITOS HUMANOS}

A Constituição Federal de 1988 inovou ao trazer no título VII - Da ordem Econômica e Financeira -, um capítulo que versa sobre a política de desenvolvimento urbano que, conforme disposto no artigo 182 da CF/88, tem como objetivo ordenar o pleno desenvolvimento das funções sociais da cidade e garantir o bem-estar de seus habitantes.

Rolnik (2011) destaca que, desde o período da Constituinte, foi articulado um movimento pela reforma urbana que movimentou desde setores sociais de luta por moradia até profissionais de várias áreas (advogados, arquitetos, urbanistas, engenheiros), além de técnicos de prefeituras e segmentos da Universidade, como forma de pressionar o Constituinte de 1988 para que ampliasse os direitos humanos e de cidadania. Assim, a mobilização resultou na inserção do capítulo de Política Urbana (artigos 182 e 183), nos quais são afirmadas a função social da cidade e da propriedade, o reconhecimento e integração dos assentamentos informais à cidade e a democratização da gestão urbana (entendida como ampliação dos espaços de participação e controle social das políticas).

O referido artigo 182, que nunca pode ser lido de forma isolada de todo o conjunto principiológico que existe no texto constitucional, destaca ser competência primordial do município a efetivação de políticas de desenvolvimento urbano tendo em vista o bem-estar social e a garantia do pleno desenvolvimento das funções sociais da cidade. Deste modo, muito embora a obrigatoriedade de políticas públicas para os espaços urbanos seja de competência de todos os entes federativos, a parcela mais ampla de atividades e obrigações está reservada ao poder municipal.

A partir da promulgação da Constituição Federal de 1988, os municípios tiveram sua autonomia reforçada, passando a assumir um papel de maior importância na prestação de serviços de interesse local. Ademais, o texto constitucional fortaleceu financeiramente os municípios através do aumento nas transferências constitucionais (ROLNIK, 2011).

Percebe-se que a atual situação de desigualdade social que assola as cidades brasileiras não é limitada ao fato de não existirem documentos legais que objetivem regrar uma boa gestão, mas sim, ao dilema político dos agentes públicos das cidades. Conforme preceitua Maria Etelvina B. Guimaraens (2002, p. 136): 
Estatuto da Cidade veio a, definitivamente, viabilizar a atuação municipal sobre os vazios urbanos nocivos para fazer cumprir a Função Social da Propriedade Urbana, estabelecendo regras gerais a partir da quais a lei municipal regulará a atuação do Poder Público Municipal e dos proprietários de imóveis urbanos, tendo como norte o adequado ordenamento urbano, a qualificação ambiental e o direito à moradia.

No que diz respeito às responsabilidades e competências no caso das desigualdades sociais urbanas, destaca-se que ao governo municipal, compete promover o ordenamento territorial ${ }^{3}$, cujo objetivo é a realização das funções sociais da cidade, a fim de que a qualidade de vida dos citadinos e da própria cidade sejam mantidas. Fernandes (2004, p. 120), refere quanto à responsabilidade do município:

Cabe especialmente ao governo municipal promover o controle do processo de desenvolvimento urbano, por meio da formulação de políticas de ordenamento territorial nas quais os interesses individuais dos proprietários de terras e construções urbanas necessariamente coexistam com os interesses sociais, culturais e ambientais de outros grupos e da cidade como um todo. Para tanto, foi dado ao poder público municipal o poder de, por intermédio de leis e diversos instrumentos urbanísticos, determinar a medida desse equilíbrio possível entre interesses individuais e coletivos quanto à utilização desse bem não renovável e essencial ao desenvolvimento sustentável da vida nas cidades, qual seja, o solo urbano.

O Estatuto da Cidade, ao seguir o disposto no texto constitucional cria instrumentos para a realização das funções sociais da cidade e da propriedade urbana. Inicialmente, traz uma definição

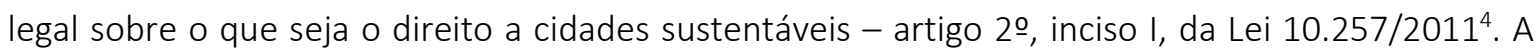
referida Lei destaca que tal paradigma deverá estar implícito e explícito em todas as políticas e planos urbanísticos, uma vez que o cumprimento das funções sociais da cidade depende da realização de políticas em prol da terra urbana, de transportes e serviços públicos, da existência de condições dignas de trabalho e de opções para o trabalho, de criação de espaços para lazer para as presentes e futuras gerações.

\footnotetext{
3 Constituição Federal. Art. 30. Compete aos Municípios: VIII - promover, no que couber, adequado ordenamento territorial, mediante planejamento e controle do uso, do parcelamento e da ocupação do solo urbano;

${ }^{4}$ Lei 10.257/2011 Art 2ㅇ A política urbana tem por objetivo ordenar o pleno desenvolvimento das funções sociais da cidade e da propriedade urbana, mediante as seguintes diretrizes gerais:Inciso I garantia do direito a cidades sustentáveis, entendido como o direito à terra urbana, à moradia, ao saneamento ambiental, à infraestrutura urbana, ao transporte e aos serviços públicos, ao trabalho e ao lazer, para as presentes e futuras gerações;
} 
As funções sociais da cidade, como interesses difusos, devem compreender o acesso, de todos ao direito à cidade para os atuais e futuros habitantes das cidades, considerando os componentes deste direito como à moradia, os equipamentos e serviços urbanos, o transporte público, o saneamento básico, à cultura e o lazer (SAULE JUNIOR, 2007, p. 54).

A partir da leitura do artigo 2으, é possível perceber que o Estatuto da Cidade inova ao tratar da ocupação do solo, não somente ao considerá-lo como a base material da cidade - infraestrutura, equipamentos públicos e prestação de serviços para todos os cidadãos; mas também, determina que a ocupação do solo urbano brasileiro seja realizada, "objetivando a melhoria dos assentamentos humanos, melhoria que requer políticas integradas que propiciem a educação, o trabalho, o lazer, o aumento da capacidade aquisitiva, o acesso à moradia, à segurança jurídica da posse, à participação democrática" (DIAS, 2012, p. 54).

Existem vários direitos fundamentais inseridos na normatividade e no pacto republicano, a exemplo dos destacados pelos artigos 5o e 6 o da Constituição Federal de 1988, que preveem que a função social da cidade será cumprida no momento em que esta proporcionar a seus habitantes o direito à vida, à segurança, à igualdade, à propriedade e à liberdade, assim como garantem a todos um piso vital mínimo, que pode ser compreendido a partir dos direitos sociais, entre os quais se encontram a educação, a saúde, o lazer, o trabalho, a previdência social, a maternidade, a infância, a assistência aos desamparados, dentre outros.

Nesse sentido, o Estatuto da Cidade funda normas de ordem pública e interesse social que regulam o uso da propriedade urbana em prol do bem coletivo, da segurança, do bem-estar dos cidadãos, enfim, do equilíbrio socioambiental, sentido em que Liana Portilho Mattos (2002) destaca:

[...] a norma que estabelece o direito às cidades sustentáveis tem seu fundamento nos princípios da dignidade da pessoa humana e da solidariedade preconizadas pela Constituição da República [...] Além disso, a concretização do princípio da dignidade da pessoa humana dá-se com a concretização dos direitos fundamentais - como o direito à cidade sustentável - irradiando todos seus efeitos sobre o ordenamento jurídico e impondo limites à atividade estatal e às relações privadas travadas no âmbito da sociedade civil e de mercado (MATTOS, 2002, p. 87-88).

Como não existe forma de identificar os sujeitos afetados pelas atividades e funções sociais da cidade, estas são caracterizadas por serem interesses difusos, uma vez que proprietários, moradores, trabalhadores, comerciantes, migrantes, têm como contingência habitar e usar um mesmo espaço territorial e que a relação estabelecida entre esses sujeitos é a própria cidade. Para Saule Junior (1997, p. 61) "a função da cidade deve atender os interesses da população de ter um 
ambiente sadio e condições dignas de vida, portanto, não há como dividir essas funções entre pessoas e grupos pré-estabelecidos, sendo seu objeto indivisível".

Nesse sentido, o Estado brasileiro produziu diretrizes inovadoras para o sistema jurídico de forma a garantir aos cidadãos o acesso a espaços urbanos sustentáveis e justos. Dias (2012) destaca que, a partir da leitura do texto constitucional, em especial de princípios constitucionais como o princípio da função social da propriedade, princípio da igualdade, da dignidade da pessoa humana, do direito à qualidade de cidade e ao meio ambiente sadio, entre outros, é possível perceber a existência de um complexo sistema normativo de regras e princípios que compõem uma nova concepção de justiça socioambiental.

Ao especificar quais seriam as funções sociais da cidade Helly Lopes Meirelles (1993, p. 377), com base na Carta de Atenas (1933), afirma que as funções sociais da cidade são quatro: habitação, trabalho, circulação e recreação. No mesmo sentido Andréas J. Krell $(2008$, p. 57) destaca que:

Já em 1933, a Carta de Atenas, documento fundamental do urbanismo moderno, assentou que as cidades devem atender, acima de tudo, as quatro necessidades fundamentais da vida do ser humano: habitar, trabalhar, recrear e circular. São estas as funções básicas a serem harmonizadas pela legislação urbanística e a sua aplicação pelos órgãos competentes.

Assim, desde 1933, quando o Congresso Internacional de Arquitetura Moderna, reuniu-se na capital grega para a formulação da Carta de Atenas, existe a concordância de que habitação, trabalho, circulação e recreação são reconhecidas como funções do espaço urbano. Conforme preceitua Meirelles (1993), as funções da cidade estabelecidas pela Carta de Atenas, influenciaram a cidade moderna, planejada, com funções delimitadas em seu espaço físico-territorial durante mais de 50 anos, tendo como marco histórico a implantação do projeto de Lucio Costa, em Brasília, a capital do Brasil.

Conforme já apresentado acima seriam quatro as funções urbanísticas: trabalhar, habitar, recrear e circular. No entanto, a fim de facilitar a questão terminológica, a recreação deu lugar ao lazer, assim como a circulação passou a ser substituída pelo termo mobilidade urbana, uma vez que os novos termos possuem maior amplitude conceitual quando comparados aos anteriores.

O trabalho é uma função primordial à vida urbana, uma vez que o trabalho, o ambiente de trabalho, a indústria, o comércio, e os serviços, são atividades fundamentais para a sustentabilidade econômica das cidades. Se não existir a possibilidade do trabalho na cidade, ela definha e acaba por desaparecer. O que pode ser alterado com o passar do tempo é a forma como o trabalho se organiza e/ou se distribui no ambiente urbano, no entanto, a função do trabalho nunca pode deixar de existir. 
Já a função da habitação corresponde ao principal refúgio do núcleo familiar, sendo fundamental à caracterização e à conceituação da cidade, uma vez que sem habitantes, não existe a cidade; sem moradias, não há cidade. O conceito de moradia, de acordo com Lins Júnior (2011) é o refúgio natural do ser humano, é o espaço onde o homem encontra conforto, intimidade e segurança, ou seja, a moradia é o lugar da vida, onde conjugam elementos que propiciam o desenvolvimento do homem.

A função social da habitação somente será concretizada com o acesso a moradia digna a todos os habitantes das cidades, no momento em que o Poder Público possuir políticas para que as populações de menor renda tenham acesso a tal direito. No entanto, não basta que o Estado forneça às pessoas quatro paredes e um teto, nas palavras de Lins Júnior (2011). Para a garantia do direito à moradia, é necessário que função social da habitação seja atingida, e, para tanto, devem ser preenchidos alguns requisitos mínimos a fim de que seja considerado garantido o direito à habitação adequada.

A Política Nacional de Habitação, aprovada em 2004, destacou o conceito de "moradia digna", como sendo:

[...] aquela localizada em terra urbanizada, com a situação de propriedade regular e com acesso a todos os serviços públicos essenciais por parte da população (transporte coletivo, água, esgoto, luz, coleta de lixo, telefone e pavimentação) e servida por equipamentos sociais básicos de educação, saúde, segurança cultura e lazer. (BRASIL, 2015c)

A Política Nacional de Habitação deve estar inserida no desenvolvimento urbano integrado, o que significa que a habitação não é restrita à casa, mas abrange o direito à infraestrutura, equipamentos e serviços urbanos e sociais, na busca pela plena garantia do direito à cidade. Observase, assim, a necessidade do preenchimento de alguns requisitos mínimos para que se considere suficientemente garantido o direito à habitação adequada, ou seja, os serviços básicos de fornecimento de água, esgoto e energia elétrica devem ser prestados de forma suficiente, e, ainda, o imóvel deve situar-se em condições geográficas seguras (LINS JÚNIOR, 2011).

Dessarte, considerando os critérios para que uma moradia seja considerada adequada, também se constata que a questão do direito à moradia não pode ser dissociada do contexto geral dos direitos econômicos, sociais e culturais, assim como de outros direitos fundamentais, como a tutela da vida privada, tudo a demonstrar a necessidade de uma tutela ampla e integrada ao direito à habitação digna e adequada (SARLET, 2011). 
A obrigação de tornar efetiva a função social da habitação exige do Estado a criação de meios materiais indispensáveis para o exercício desse direito, através de medidas como: a adoção de instrumentos financeiros, legais, administrativos, fiscais, urbanísticos e de regularização fundiária para a promoção de uma política habitacional; constituição de um sistema nacional de habitação de interesse social, descentralizado, com mecanismos de participação popular e recursos subsidiados; revisão de legislação e instrumentos de modo a eliminar normas que acarretem algum tipo de restrição e discriminação sobre o exercício do direito à moradia; imediata implementação de legislações e instrumentos de garantia do direito à moradia; destinação de recursos públicos para a política habitacional (OSÓRIO; SAULE JUNIOR, 2003).

No entanto, o alto custo da terra urbana, fruto da especulação imobiliária, é um dos fatores que vem dificultando o acesso das pessoas de menor renda à moradia, além de acarretar uma nítida redução dos espaços públicos nas cidades - intimamente ligados à função urbanística do lazer - ou seja, os centros de lazer para a comunidade, praças, lugares de convivência ou de sociabilidade estão cada vez mais escassos, ao passo que os espaços são cada vez mais cercados por muros, limitados à circulação de pessoas, com segurança intensa.

A função do lazer é importante para a realização integral do ser humano e abrange os espaços de recreação, de encontro, do contato social, entre os moradores do ambiente urbano. É geralmente nos contatos propiciados através do lazer que nascem os relacionamentos humanos em todas as esferas, desde a familiar até as amizades, a solidariedade, o sentimento de unidade e de grupo.

Estando o lazer inserido no rol do artigo 6o da Constituição Federal, é um direito social inserido na dimensão dos direitos fundamentais do ser humano, a fim de possibilitar uma melhor condição de vida aos citadinos. Nesse sentido, o Poder Público deve propiciar a todos os habitantes das cidades, espaços adequados e prósperos a recreação e lazer. Assim, para que o lazer cumpra com sua função social na cidade, é imprescindível a universalização dos ambientes públicos, a fim de que esses sejam acessíveis a todos os segmentos sociais, de acordo com suas características, costumes, tradições e necessidades.

Ainda, as áreas de lazer e recreação são aquelas destinadas à implantação de equipamentos comunitários, como ocorre com as praças, estádios públicos, parques; ou também podem ser os espaços livres de uso comum, a exemplo de jardins e praias, sendo o reconhecimento de áreas de lazer condicionado ao exercício de atividades prazerosas, seja a nível físico ou mental.

Conforme Freitas (1999, p. 186), as áreas de lazer constituem-se de todo "espaço público de loteamento destinado ao sistema de circulação, à implantação de equipamento urbano e comunitário, áreas verdes, espaços livres de uso público, vias, praças e jardins, e áreas destinadas a 
edifícios públicos". Nesse sentido, para que o lazer seja efetivado, elementos tradicionais das cidades devem ser preservados, entre eles, a memória, a identidade do meio ambiente urbano, o que inclui os locais onde se efetiva o lazer, entre os quais, praças. parques, bairros históricos, espaços abertos e verdes.

Por fim, a última função social da cidade é a mobilidade urbana, que pode ser entendida como um processo integrado de fluxos de pessoas e bens que envolvem todas as formas de deslocamentos dentro do ambiente urbano, seja nos modos rodoviário, ferroviário e hidroviário, seja através do transporte público, privado, coletivo, individual, motorizado, não-motorizado, ou, até mesmo, a pé. A mobilidade urbana é definida pela Secretaria Nacional de Transporte e Mobilidade Urbana do Ministério das Cidades como a facilidade de deslocamento das pessoas e bens na cidade, tendo em vista a complexidade das atividades econômicas e sociais nele desenvolvidas (SEMOB, 2005).

Destaca-se que a Constituição Federal de 1988, preceitua em seu artigo 30, inciso V, que o transporte coletivo é um serviço público de caráter essencial. Ao caracterizá-lo como essencial, o texto constitucional afirma ser o transporte coletivo um serviço fundamental e necessário para a concretização das funções sociais da cidade. Assim, cabe ao Poder Público efetivar a função social da mobilidade urbana aos citadinos, através da garantia do acesso ao transporte coletivo urbano a todos os moradores da cidade, sem nenhum tipo de exclusão, seja por falta de condições de acessibilidade física, econômica ou qualquer tipo de discriminação, através da universalização dos serviços.

Percebe-se, claramente, que tanto a Constituição Federal quanto o Estatuto da Cidade, através da definição das funções sociais da cidade, impulsionam o poder público, isto é, todos os entes políticos da Federação, a lutarem por espaços urbanos mais qualitativos, menos excludentes, em que todos os citadinos possam efetivamente vivenciar a cidadania. No entanto, para que as funções sociais da cidade de habitar, circular, trabalhar e desfrutar do lazer nos espaços urbanos sejam concretizadas, é preciso que a prestação de serviços públicos seja efetiva. Em outras palavras,

o pleno desenvolvimento das funções sociais da cidade implica a necessária atuação e intervenção dos entes federativos - no âmbito de suas competências - no sentido de planificar metas e ações para o pleno desenvolvimento das funções sociais da cidade. As funções sociais da cidade devem expressar o acesso ao uso dos espaços urbanos, em igualdades de condições para todos (DIAS, 2012, p. 19).

Ademais, a participação dos indivíduos na administração dos espaços urbanos, por meio da gestão democrática das cidades, é imprescindível para que sejam efetivadas as funções sociais da 
cidade. Os citadinos possuem a capacidade de ponderar interesses privados e interesses públicos colidentes, a fim de que sejam produzidos parâmetros técnico-legais lídimos, decorrentes da correta ponderação de interesses para a realização dos objetivos nacionais para o desenvolvimento urbano e para o cumprimento da função social da propriedade, que devem ser expressos em um instrumento basilar para o processo de planejamento e desenvolvimento de políticas urbanas: o plano diretor - instrumento obrigatório para políticas de desenvolvimento urbano para cidades com mais de 20.000 habitantes (DIAS, 2012). Quanto ao plano diretor, Saule Junior (1997, p. 230), destaca que:

O plano diretor, para ser um instrumento eficaz destinado a tornar efetivo esses direitos, tem como pressuposto que suas normas estão em plena consonância com a cidadania e a dignidade da pessoa humana, fundamentos do Estado Democrático de Direito, bem como aos princípios da soberania popular (democracia direta, participação popular), da igualdade, do desenvolvimento sustentável, das funções sociais da cidade, da função social da propriedade.

É através do plano diretor que o desenvolvimento das funções urbanísticas municipais tornase possível, possibilitando melhores espaços para trabalhar, circular, recrear, viver. Meirelles (1993, p. 377) considera o urbanismo como uma ciência, técnica e arte, que objetiva a organização do espaço urbano tendo em vista o bem-estar da coletividade, "através de uma legislação, de um planejamento e da execução de obras públicas que permitam o desempenho harmônico e progressivo das funções urbanas elementares: habitação, trabalho, recreação, circulação no espaço urbano".

No mesmo sentido, Dias (2012, p. 20-21) destaca que o plano diretor "é o instrumento que traz ínsitas estratégias de mudança para os espaços urbanos que propiciem melhorias e facilidades à vida social, econômica, política, cultural, ambiental, no município, permitindo melhor qualidade de vida e bem-estar para todos". Importante referir, ainda, a norma constitucional expressa no artigo 182, que destaca que a política de desenvolvimento urbano não se restringe às áreas urbanas, mas sim, deve tratar das interações e influências entre áreas rurais e urbanas. Ademais, seria muito reducionista considerar que seja somente nos espaços urbanos que o município tenha o dever de primar pelo desenvolvimento das funções sociais da cidade.

O pleno desenvolvimento das funções da cidade pressupõe a interação entre interesses econômicos e políticos a fim de que a exclusão, as diferenças e a marginalização sociais sejam dissolvidas, e que seja efetivado um ambiente urbano em que todos tenham acesso aos mesmos 
direitos e serviços. Ademais, o meio ambiente natural onde se desenvolvem as cidades deve ser preservado, para que seja possível uma vida digna às gerações atuais e futuras.

Desta maneira, conforme preceitua Dias (2012), o desenvolvimento das funções sociais somente será eficaz no momento em que atingir o bem-estar geral, ou seja, o atendimento de todos os cidadãos em suas necessidades como moradia, lazer, circulação e trabalho; além de outros direitos decorrentes da possibilidade de constituição de espaços urbanos sustentáveis. Assim, deve partir dos habitantes da cidade o interesse de que as funções sociais da cidade sejam plenamente desenvolvidas, o que abrange qualquer grupo social, uma vez que a lei não estabelece qualquer tipo de distinção entre categorias de cidadãos, seja pelo fator econômico, social, de raça, cor, sexo, ou idade, abrangendo todos os habitantes como cidadãos (SAULE JUNIOR, 2007, p. 53).

Ademais, a implementação de políticas públicas deve ocorrer em todos os espaços urbanos a fim de que as funções sociais da cidade sejam efetivadas, em especial naqueles onde a ação estatal está ausente, nos quais inexistem serviços e condições básicas à vida na cidade, em locais em que a população carente não é beneficiada pelos serviços essenciais relacionados ao trabalho, habitação, lazer e mobilidade urbana.

O homem estabeleceu, no decorrer do tempo, funções sociais para a cidade e buscou fazer com que essas fossem validadas, através da cultura, da construção de ambientes urbanos e das normas legais. $\mathrm{Na}$ atual sociedade a cidade transcende o seu limite geográfico, em decorrência da facilidade de informação e mobilidade. Assim, as funções sociais da cidade passam a ser independentes do espaço/tempo, para se constituírem em direitos que acompanham o ser humano onde ele estiver.

A execução da política urbana que objetiva ao pleno desenvolvimento das funções sociais da cidade passa pela necessidade de salvaguarda de interesses difusos de todos, da comunidade. É preciso considerar que o desenvolvimento das funções socais da cidade e seu uso interferirá diretamente na possibilidade e consecução de uma vida mais digna para todos (DIAS, 2012). Portanto, verifica-se que as funções sociais da cidade estão intimamente ligadas aos direitos humanos.

Pela teoria da finalidade ${ }^{5}$ o Poder Público existe para garantir e materializar os direitos humanos, entre os quais se insere direito à vida social, com liberdade e limites que possam assegurar a todos condições de igualdade de usufruir dos bens gerados pela civilização. Assim, planejar e

\footnotetext{
${ }^{5}$ Nesse sentido, ao discorrer sobre a teoria da finalidade Aristóteles (apud CORRÊA, 2006), apresenta a concepção do jusnaturalismo ao tratar da justiça distributiva e da justiça comutativa, sendo o direito um sinônimo de justiça e o critério a ser levado em conta era o justo por natureza física e social (teoria da finalidade). Assim, o direito enquanto justiça está na natureza entendida no seu todo e não apenas ou essencialmente enquanto natureza do homem.
} 
executar políticas futuras para os espaços urbanos com alicerces sustentáveis requer considerações sobre as necessidades dos citadinos que compõem os diferentes grupos de interesses econômicos o políticos e que formam a base das relações sociais e determinam o uso, a ocupação, a transformação do espaço físico, bem como determinam a configuração das relações sociais entre estes citadinos que indiscutivelmente vivenciam diferentes formas de cidade nos espaços urbanos que habitam (DIAS, 2012).

Para tanto, a gestão democrática da cidade surge como instrumento importante na busca pela efetivação das funções sociais da cidade, que visa gerar melhores condições de vida aos citadinos, no momento em que os princípios da dignidade humana e da cidadania (entendida como a garantia dos direitos e deveres de todos os cidadãos independente das condições em que se encontrem) forem respeitados, uma vez que é fundamental que a discriminação e as desigualdades sociais sejam reduzidas para que os direitos humanos sejam efetivados.

\section{A GESTÃO DEMOCRÁTICA E AS FUNÇÕES SOCIAIS DAS CIDADES}

O elemento democrático é essencial para que seja possível atingir a igualdade no acesso aos serviços, aos equipamentos públicos, à fruição das funções sociais da cidade, desejada pelo ordenamento jurídico. A democracia é a base do Estado Democrático de Direito e tem por fundamentos o exercício da cidadania e a proteção da dignidade da pessoa humana.

O conteúdo democrático é transformador uma vez que busca a igualdade, a melhoria das condições existenciais dos cidadãos, a realização da dignidade humana. Conforme preceituam Streck e Morais (2001), o elemento democrático não deve ser somente um elemento de qualificação do Estado, mas também deve definir a estrutura deste, suas funções, suas atribuições, ao difundir o valor da democracia sobre todos os seus elementos constitutivos, bem como sobre a ordem jurídica.

A proteção aos direitos fundamentais busca limitar o poder do Estado e de outras instituições, além de implicar no reconhecimento dos indivíduos como sujeitos de direitos, isto é, na possibilidade de serem atores de sua própria história. Ao defender a ideia do direito à cidade como um direito fundamental, Saule Junior (2007, p. 50) destaca que:

[...] o direito à cidade tem como elementos os direitos inerentes às pessoas que vivem nas cidades em ter condições dignas de vida, de exercitar plenamente cidadania e direitos humanos (civis, políticos, econômicos, sociais, culturais e ambientais), de participar da gestão da cidade, de viver num meio ambiente ecologicamente equilibrado e sustentável. 
Nesse sentido, a realização do processo democrático na gestão da cidade é uma das razões de existência do Estatuto da Cidade, vez que o próprio estatuto é resultado de uma longa história de participação popular, iniciada na década de 80 (DALLARI; FERRAZ, 2003). Assim, no momento de luta pela redemocratização do país surgiu um processo de promoção da reforma urbana, baseada nos princípios de inclusão social e sustentabilidade, e que, atualmente, é possível afirmar que a participação dos cidadãos nos programas de gestão urbana é imprescindível para o sucesso dos mesmos, bem como para a efetivação das funções sociais da cidade.

Em decorrência de tais movimentos sociais, a própria Constituição Federal de 1988 acolheu os princípios de inclusão social e sustentabilidade ambiental ao dispor que o princípio da função socioambiental da propriedade e da cidade e os processos e mecanismos tradicionais de representação popular devem ser combinados com processos e mecanismos mais inovadores de participação direta no processo decisório das questões urbanas, especialmente no contexto da ação do governo local (FERNANDES, 2012, p. 21). O autor ainda refere que:

Ao combinar os princípios da função socioambiental da propriedade e da cidade e o da gestão democrática da cidade, o novo paradigma conceitual proposto pela Constituição Federal de 1988 implica reconhecer que não há como discutir o lugar do direito no processo de urbanização sem também pensar a ordem jurídica da perspectiva das condições sociopolíticas e jurídicoinstitucionais de gestão da cidade. Direito e gestão urbana são duas questões que não podem mais ser dissociadas, e qualquer proposta de se pensar o direito criticamente tem que levar em conta as quatro dimensões profundamente inter-relacionadas que constituem a ordem jurídicourbanística.

Por meio do capítulo da Política Urbana ao determinar a concretização da dignidade humana, a Constituição Federal objetiva a diminuição das desigualdades sociais presentes nos centros urbanos, representadas entre outras, pela segregação socioespacial. Conforme destaca Dias (2012), o Estado vem, por meio da Constituição Federal e do Estatuto da Cidade constituir um novo marco legal, paradigma para o gerenciamento das cidades como forma de promover a integração social e territorial da população; "no sentido de conciliar a representação democrática tradicional com a participação direta dos cidadãos e com a possibilidade de ampla renovação das relações entre Estado e sociedade" (FERNANDES, 2012, p. 24). A fim de que seja possível a concretização dessa nova forma de planejamento e gerenciamento dos espaços urbanos as decisões devem se pautar em práticas democráticas.

Nesse sentido, o Estatuto da Cidade - Lei 10.257/2001 - vem estabelecer, em seu artigo 2으, inciso II, a diretriz da gestão democrática "por meio da participação da população e de associações 
representativas dos vários segmentos da comunidade na formulação, execução e acompanhamento de planos, programas e projetos de desenvolvimento urbano". A gestão democrática da cidade tem base nos preceitos constitucionais de democracia participativa, cidadania, soberania e participação popular.

É certo que a gestão democrática implica na participação da população e de associações representativas dos mais diversos segmentos da comunidade a fim de que possa, deste modo, formular, executar e acompanhar planos, programas e projetos de desenvolvimento urbano. Pela gestão democrática, a participação popular se realiza em todas as fases do processo de planejamento, razão pela qual é uma diretriz determinante para o poder público, já que prevê uma nova forma de conduta, de direcionamento dos processos de decisão no que diz respeito à política de desenvolvimento urbano (DIAS, 2012).

Por sua vez, o capítulo 4ํ do Estatuto da Cidade $^{6}$, trata especificamente da gestão democrática da cidade. Apresenta os instrumentos por meio dos quais se garantirá a gestão democrática dos espaços urbanos.

É possível observar que o artigo 43 relaciona alguns instrumentos específicos - mas não taxativos - para a garantia da plena realização da gestão democrática. O sentido do Capítulo IV,

[...] garantir, não apenas como princípio, mas como diretriz de "operação" da nova ordem jurídico-urbanística, "a participação da população e de associações representativas dos vários segmentos da comunidade na formulação, execução e acompanhamento de planos, programas e projetos de desenvolvimento urbano" (art. 2으. II, do Estatuto da Cidade) (DALLARI; FERRAZ, 2003, p. 336).

Os instrumentos participativos não podem ser considerados como a única abertura democrática fora da representação política, bem como não é possível tomar os canais participativos previstos por lei como concessões do Estado para calar a batalha pela construção, no cerne da

\footnotetext{
${ }^{6}$ Lei 10.257/2011. Capítulo IV Da Gestão Democrática da Cidade Art. 43. Para garantir a gestão democrática da cidade, deverão ser utilizados, entre outros, os seguintes instrumentos: I - órgãos colegiados de política urbana, nos níveis nacional, estadual e municipal; II - debates, audiências e consultas públicas; III conferências sobre assuntos de interesse urbano, nos níveis nacional, estadual e municipal; IV - iniciativa popular de projeto de lei e de planos, programas e projetos de desenvolvimento urbano; $V$ - (VETADO) Art. 44. No âmbito municipal, a gestão orçamentária participativa de que trata a alínea $\mathrm{f}$ do inciso III do art. 4odesta Lei incluirá a realização de debates, audiências e consultas públicas sobre as propostas do plano plurianual, da lei de diretrizes orçamentárias e do orçamento anual, como condição obrigatória para sua aprovação pela Câmara Municipal.

Art. 45. Os organismos gestores das regiões metropolitanas e aglomerações urbanas incluirão obrigatória e significativa participação da população e de associações representativas dos vários segmentos da comunidade, de modo a garantir o controle direto de suas atividades e o pleno exercício da cidadania.
} 
sociedade, de um conceito amplo de cidadania. No entanto, é necessário reconhecer que a previsão legal dos mecanismos de participação é uma das grandes vitórias da cidadania.

Conforme anteriormente destacado, a gestão democrática da cidade ratifica o sentido e a configuração do Estado Democrático de Direito, na busca pela realização da igualdade, a partir da vivência da democracia. Conforme define o artigo 43 do Estatuto da Cidade, a atuação estatal, o cumprimento de suas competências, a implementação de políticas públicas, inclusive, a proposição de projetos de leis, planos e programas para o desenvolvimento urbano, dependerão do diálogo, que Dias (2012) destaca como uma "concertação de interesses" entre a sociedade e o Estado.

Os incisos I a IV do artigo 43, da Lei 10.257/01, são evidentemente prova de que existe uma mudança paradigmática na forma de gestão urbana que deve pautar-se, conforme referido na lei, na existência de órgãos colegiados de política urbana, em todos os âmbitos da Federação - federal, estadual e municipal; na necessária abertura democrática por meio de debates, audiências e consultas públicas; na necessária realização de conferências sobre os assuntos urbanos, em todos os níveis da Federação, e ainda, na possibilidade de participação direta dos cidadãos por meio da iniciativa popular de projeto de lei, planos, programas e projetos de desenvolvimento urbano.

As políticas urbanas brasileiras sempre foram determinadas "de cima para baixo", sem escutar os cidadãos e sem considerar o que estes entendem por necessidades ou por soluções para os problemas por que passam as cidades. Ao instituir a gestão democrática da cidade, o Estatuto da Cidade propõe que ocorra uma gestão urbana "concertada", conforme preceitua Dias (2012), na qual o poder público deve tomar suas decisões a respeito do desenvolvimento urbano, pautado em um diálogo traçado com a população como única forma de legitimar as políticas públicas para os espaços urbanos. Nesse sentido, Coutinho (1984, p. 41), refere que:

O fortalecimento da sociedade civil abre assim a possibilidade concreta de intensificar a luta pelo aprofundamento da democracia política no sentido de uma democracia organizada de massas que desloque cada vez mais "para baixo" o eixo das grandes decisões hoje tomadas exclusivamente "pelo alto".

Em uma ideia complementar, Régis Fernando de Oliveira (2002, p. 109), refere que:

A ideia de gestão autoritária, em que as decisões eram tomadas no interior de gabinetes e simplesmente impostas à população, é coisa do passado. Modernamente, exige-se que o administrador público não só tenha competência para tomar decisões, mas que este tome em sintonia com o que o povo pretende. o gestor da coisa pública deve ter sensibilidade para ouvir a comunidade a que serve. 
Em termos políticos, tem-se a necessidade da participação popular combinada com a participação direta no processo decisório e na gestão urbana, para que a democracia seja efetivamente vivenciada, e que as funções sociais da cidade sejam realizadas, uma vez que os mecanismos tradicionais de democracia dificultam os grupos socialmente mais vulneráveis em ter seus interesses representados no sistema político. A distância entre os cidadãos e a tomada de decisões políticas, as mantém incapazes de compreender a dimensão das situações, o que acarreta em uma atuação estatal autoritária, ineficaz e puramente representativa.

Diante disso, debates, audiências públicas, consultas públicas, conferências sobre assuntos de interesse humano, nos níveis nacional, estadual e municipal; iniciativa popular de projetos de lei e de planos, programas e projetos e desenvolvimento urbano; existência de órgãos colegiados de política urbana em todos os níveis da federação, são alguns dos instrumentos imprescindíveis para a efetivação de práticas democráticas no processo de planejamento e desenvolvimento urbanos (DIAS, 2012). A gestão democrática da cidade busca,

Potencializar o exercício do direito à cidade que tem como componentes os direitos políticos e da cidadania coletivos dos habitantes das cidades deve constituir o objetivo a ser respeitado nos processos de gestão nas cidades. 0 direito à cidade será respeitado quando os grupos sociais marginalizados e excluídos tiverem acesso à vida política e econômica da cidade. Este direito, para ser exercido, pressupõe a capacitação política destes grupos sociais (SAULE JUNIOR, 2007, p. 56).

No entanto, opor direitos gerais e regras administrativas que normalizem a minoria e visem à segurança da maioria não é suficiente. É preciso sim, aumentar a capacidade de expressão e de iniciativa dos que devem ser reconhecidos como atores e não apenas como vítimas, isto porque nos países onde as liberdades fundamentais são respeitadas, a democracia depende da reorganização da vida política pela formação de novos movimentos sociais e pela renovação da análise social a política (TOURAINE, 1996, p. 149).

Nessa perspectiva,

O ideal democrático supõe cidadãos atentos à evolução da coisa pública, informados dos acontecimentos políticos, ao corrente dos principais problemas, capazes de escolher entre as diversas alternativas apresentadas pela forças políticas e fortemente interessados em formas diretas ou indiretas de participação. Numerosas pesquisas levadas a cabo nos últimos decênios demonstram claramente que a realidade é bem diferente (BOBBIO, 2000, p. 889).

Ao conjeturar o instituto da gestão democrática das cidades, a partir do Estatuto da Cidade 
e da análise dos princípios constitucionais que expressam os direcionamentos para a efetivação das funções sociais da cidade nos espaços urbanos, percebe-se que a configuração dos espaços de tomada de decisões deve se caracterizar por um processo que se inicia com a tomada de conhecimento sobre as necessidades dos cidadãos, a partir da visão desses sobre os espaços urbanos que habitam, em um procedimento que permita a tomada de decisões e participação política dos citadinos (DIAS, 2012).

Assim, o uso dos institutos trazidos pelo Estatuto da Cidade, em especial no que se refere à gestão democrática das cidades, faz-se imprescindível, uma vez que o

[...] cumprimento do direito à cidade é extensivo ao desenvolvimento de processos democráticos de planejamento, que tem como peças fundamentais o plano plurianual, a lei de diretrizes orçamentária, o orçamento municipal e o plano diretor dos Municípios em que for obrigatório.

Atuam, assim, conjuntamente com a comunidade e o Estado na gestão e fiscalização da coisa pública. A gestão democrática da cidade pressupõe a organização da sociedade civil, para interferir no processo político em nome das demandas sociais por meio do exercício da cidadania (SAULE JUNIOR, 2007, p. 56).

Para que a gestão democrática se concretize, ela depende da conscientização de todos sobre o real sentido de cidadania. E mais, o processo de tomada de decisão deve ser seguido, obrigatoriamente, pela prestação de contas, através da qual a população, as associações representativas, entre outros, devem realizar o controle sobre o poder público, pois possuem a legitimidade para fiscalizar a forma como estão sendo gerenciados os espaços urbanos (DIAS, 2012).

Outrossim, a gestão democrática engloba a criação de órgãos de política urbana que propiciem o debate e o diálogo em todos os níveis da federação - federal, estadual e municipal - não se referindo somente aos procedimentos e tomadas de decisão no âmbito local. Senão veja-se:

Em nível federal, o estabelecimento do conselho de desenvolvimento urbano deve objetivar um processo de decisório democrático, no qual todos os membros e segmentos que componham o conselho sejam possibilitados de participar das decisões, em igualdade de condições (DIAS, 2012). 0 mesmo deve ocorrer no âmbito estadual.

Conforme o artigo 25, § 3o, da Constituição Federal de 1988, cabe aos Estados, mediante lei complementar instituir regiões metropolitanas, aglomerações urbanas e microrregiões. Entenda-se inseridos nesses conceitos os agrupamentos de municípios limítrofes, a fim de integrar a organização, o planejamento e a execução de funções públicas de interesse comum. Nesse sentido, o artigo 45 da Lei 10.257/2001 prevê, como exemplo de gestão democrática, a inclusão pelos gestores das regiões metropolitanas e aglomerações urbanas, e significativamente da participação 
da população e de associações representativas dos vários segmentos da comunidade, como forma de garantia do controle direto de suas atividades, bem como do pleno exercício da cidadania.

Do mesmo modo que no âmbito federal e estadual, o planejamento urbano municipal - que inclui a criação de planos diretores, de planos especiais, de planos, programas e projetos setoriais, de todo o processo de planejamento para o parcelamento, uso e ocupação do solo, assim como o plano plurianual, as diretrizes orçamentárias e o orçamento anual - não pode realizar-se sem a devida participação popular, como forma de se legitimar o processo de planejamento municipal, conforme preceitua o artigo 4ㅇ, inciso III, alínea "a", do Estatuto da Cidade. Nesse sentido, Fernandes (2012, p. 26) refere:

O reconhecimento pelos municípios de processos e mecanismos jurídicopolíticos adequados que garantam a participação efetiva dos cidadãos e associações representativas no processo de formulação e implementação do planejamento urbano e das políticas públicas - mediante audiências, consultas, conselhos, estudos de impactos de vizinhança, iniciativa popular na propositura de leis e sobretudo por meio das práticas do orçamento participativo - é tido como o Estatuto da Cidade como sendo essencial para a promoção da gestão democrática da cidade. Além disso, a nova lei enfatiza a importância do estabelecimento de novas relações entre o setor estatal, o setor privado e o setor comunitário, especialmente por meio de parcerias e operações urbanas consorciadas, que têm de se dar dentro de um quadro jurídico-político clara e previamente definido, incluindo a criação de mecanismos transparentes de controle fiscal e social.

Percebe-se que os cidadãos possuem importância singular na promoção do direito à cidade, pois, por serem sujeitos centrais da democracia, acredita-se que tenham melhores condições de apresentar uma visão mais crítica sobre as cidades. Assim, para que a gestão democrática das cidades seja concretizada é preciso que os citadinos se reconheçam como entes ativos na promoção das funções da cidade, a fim de que seja possibilitado o desenvolvimento urbano baseado na sustentabilidade, com o objetivo de diminuir as desigualdades sociais, de modo que as cidades transformem-se em centros de inclusão social, solidariedade e convivência pacífica.

Conforme Nalini (2011, p. 134) "a cidade seria diferente se o seu habitante fosse mais proativo", uma vez que um dos principais problemas da sociedade brasileira é o fato de os citadinos terem se transformado em meros espectadores da gestão do espaço público, o que possibilita com que esse espaço público seja ocupado pela ação demagógica dos governantes, e resulta nas mais latentes desigualdades sociais, que podem ser representadas, entre outras, pela segregação socioespacial. A fim de reverter tal situação de passividade, Gomes (2012) defende que o desafio atual é o de retomar o espaço público como local de participação ativa dos citadinos, normatizada (entre outros documentos pelo Estatuto da Cidade) a fim de refunda-lo como um espaço da política. 
No mesmo sentido, Cenci (2010), ao tratar o tema do urbanismo contemporâneo, destaca que o indivíduo precisa ser compreendido como elemento central no espaço, na realização de suas atividades correspondendo à ideia de sociabilidade necessária, ou seja, a nova relação da dinâmica da vida atual constante na interação com outros indivíduos.

A gestão democrática das cidades, a fim de que se atinja um desenvolvimento sustentável e a efetivação das funções sociais da cidade, exige conhecimentos interdisciplinares, planejamento intersetorial e, em especial, participação dos citadinos na tomada de decisões a fim de que se atinja o processo de governabilidade democrática instituído pelo Estatuto da Cidade. Leff (2004, p. 62) destaca que:

os princípios de gestão ambiental e de democracia participativa propõem a necessária transformação dos Estados nacionais e da ordem internacional para uma convergência dos interesses em conflito e dos objetivos comuns nos diferentes grupos e classes sociais em torno do desenvolvimento sustentável e da apropriação da natureza. O fortalecimento dos projetos de gestão ambiental local e das comunidades de base está levando os governos federais e estaduais, como também intendências e municipalidades, a instaurar procedimentos para dirimir pacificamente os interesses de diversos agentes econômicos e grupos de cidadãos na resolução de conflitos ambientais, através de um novo contrato social entre o Estado e a sociedade civil.

Fernandes (2012) refere que apesar de a Constituição Federal brasileira ter avançado ao trazer a ideia da participação direta, a ordem político-social vigente até hoje não expressa essa natureza dinâmica, coletiva e contraditória do processo político mais amplo. Complementa, ao afirmar que é preciso um esforço transdisciplinar que consista na criação de pontes teóricas entre juristas, arquitetos, urbanistas, sociólogos, economistas, historiadores, geógrafos, antropólogos e cientistas políticos, para que seja produzido conhecimento sobre o processo de urbanização, uma vez que:

A ciência faz parte do complexo da cultura a partir do qual esta tenta encontrar coerência intelectual e ordenar as vias pelas quais orienta sua investigação. Há uma retroalimentação por ressonâncias, pelas interpretações dadas, em cada época, às teorias científicas, e a educação tem sido encarregada, em todos os tempos, de reproduzir os ideais sociais, econômicos e políticos predominantes (KEITEL; PEREIRA; BERTICELLI, 2012, p. 135).

Além disso, é imprescindível que todos esses pensadores e operadores da cidade entendam o papel crucial que o direito tem tido na determinação do processo de segregação socioespacial - e que pode vir a ter na promoção da reforma urbana baseada nas funções sociais da cidade. 
Nesse sentido, a gestão democrática da cidade, a fim de que se atinja o desenvolvimento sustentável e que sejam realizadas as funções sociais da cidade exige novos conhecimentos interdisciplinares e planejamento intersetorial, mas, principalmente, um processo de governabilidade democrática. Conforme Fernandes (2004, p. 114), tanto a reforma urbana, quanto a reforma judiciária e a reforma do setor público devem andar juntas, em um quadro referencial de uma agenda progressista de governança urbana.

Deve ser construída uma ética urbana baseada na justiça social, na cidadania e na viabilização das transformações necessárias para a cidade exercer sua função social. Para tanto, os citadinos devem se unir para que o direito fundamental à cidade seja efetivado, o que depende da própria realização humana; pois, como a compreensão da realização da cidadania está diretamente relacionada com participação social, as desigualdades sociais que acometem as cidades atualmente, demonstram que a concretização da cidadania está intrinsecamente vinculada ao acesso dos citadinos à gestão urbana, que se dá pela gestão democrática, a fim de que as cidades cumpram com sua função social.

A gestão democrática remete, assim, à ideia de um novo pacto territorial, em que o Direito não se distancie da Justiça, mas garanta que a cidade seja espaço de convivência de todos os seus habitantes, onde cada um possa desenvolver plenamente suas potencialidades (DALLARI; FERRAZ, 2003). Ou seja, a cidade, como espaço onde a vida se desenrole, com suas funções sociais: fornecer às pessoas moradia, trabalho, saúde, educação, cultura, lazer, transporte.

Isto é, para que o direito à cidade seja plenamente efetivado, é imprescindível o cumprimento do dever de defesa desse espaço, dever esse de toda coletividade. Conforme refere Elisa Ceriolli Del'Olmo (2009, p. 233), cogente se faz “a participação do cidadão por meio do exercício da cidadania e a ampla consciência individual e coletiva da necessidade permanente da proteção contínua e sistemática da natureza como condição de qualidade de vida e da própria sobrevivência humana".

Por fim, a gestão democrática é uma forma de política urbana na qual se busca que o planejamento urbano ocorra por meio da participação popular, seja de maneira individual, seja de maneira coletiva, ou por meio de organizações não governamentais. 0 importante é que na gestão democrática o planejamento urbano não deve ser idealizado em gabinete e posteriormente aplicado à realidade urbana. Assim, o instituto prevê a cooperação entre o governo, a iniciativa privada e demais setores da sociedade no processo de urbanização, a fim de que as funções sociais da cidade sejam concretizadas.

\section{A RELEVÂNCIA DA CIDADANIA NA GESTÃO DEMOCRÁTICA E A PROMOÇÃO DOS DIREITOS HUMANOS}


Pela leitura dos artigos do Estatuto da Cidade referentes à gestão democrática, é possível perceber que é de responsabilidade do poder público a criação de canais para que os citadinos e as associações representativas possam deliberar sobre os espaços urbanos, em conjunto poder público e privado, posto que o Estatuto da Cidade, ao estabelecer formas de participação direta e semidireta dos citadinos na gestão e formulação de políticas públicas nas áreas urbanas, optou por mitigar a democracia representativa.

Ao destacar a importância que o Estatuto da Cidade traz sobre a gestão democrática, Dias (2012, p. 66), refere que "a participação democrática é um processo permanente dentro do processo de planejamento urbano". Assim, é possível perceber que se faz necessário o reconhecimento da responsabilidade social e da democracia na tomada de decisões sobre elementos centrais da vida que dizem respeito à totalidade da sociedade.

Os planejadores, gestores e reformadores urbanos precisam retomar a solidariedade, o direito, a cidadania na gestão das cidades, a fim de que se diminua a expansão urbana bipartida em ricos e pobres, posto que, por meio da gestão democrática das cidades, torna-se possível a avaliação de interesses coletivos visando reduzir a desigualdade social, fazendo com que as cidades tornemse o local ideal para que os direitos humanos sejam efetivados, uma vez que é na cidade que ocorre a gerência da vida da sociedade.

É imprescindível que o direito à cidade seja respeitado para que as cidades efetivem suas funções sociais. Assim preleciona Saule Júnior (2007):

O respeito ao direito à cidade é o principal indicador para verificar o estágio das cidades brasileiras estarem desenvolvendo as suas funções sociais. Quanto maior for o estágio de igualdade, de justiça social, de paz, de democracia, de harmonia com o meio ambiente, de solidariedade entre os habitantes das cidades, maior será o grau de proteção e implementação do direito à cidade (SAULE JUNIOR, 2007, p. 64).

A gestão democrática deve buscar um desenvolvimento que vise combater as desigualdades, o uso irresponsável dos recursos naturais, ou seja, o desenvolvimento sustentável por meio do planejamento urbano mais humano, menos excludente, objetivando a vida digna com qualidade para a maior parte da população. Portanto, o Estado e a comunidade devem, conjuntamente, fiscalizar o espaço público, a fim de que sejam diminuídas as desigualdades.

Para que se atinja tal grau de igualdade, os direitos políticos precisam ser potencializados e respeitados no processo de gestão dos espaços urbanos, visto que o direito à cidade somente será efetivado no momento em que todos os grupos sociais, em especial os excluídos e marginalizados, 
tiverem acesso à vida política e econômica. Somente no momento em que os grupos sociais mais vulneráveis forem reconhecidos como parte integrante na formação da gestão democrática das cidades, é que haverá o cumprimento do direito à cidade, através da efetivação de suas funções sociais. Caso contrário, a realidade urbana nunca deixará de ser a de muros e segregações, conforme estabelece Caldeira (1997).

É possível constatar que o direito à cidade busca a proteção dos cidadãos, que apesar de suas diferenças, devem ser reconhecidos como portadores de direitos fundamentais. Nesse sentido, Nalini (2011) refere sobre a necessidade de alertar aqueles cujas consciências foram suprimidas, bem como destaca o dever da comunidade pensante na busca pela igualdade.

É urgente retirar da inércia a massa letárgica daqueles eticamente anestesiados, pois a missão do resgate do semelhante de sua servidão não é exclusiva do governo. É missão salvífica que deve se encarregar a cidadania. Só assim se reduzirá a larga distância hoje constatável entre incluídos e excluídos, entre senhores e servos, entre os exitosos e os desprovidos de qualquer perspectiva (NALINI, 2011, p. 19).

Assim, pensar a urbanização é refletir o que está ocorrendo nos espaços urbanos, bem como o que está sendo feito com tais espaços. Para que se atinja a tão desejada igualdade, é necessário que ocorra uma mudança no atual modelo de cidade, modelo este que, conforme preceitua Freitag (2013, p. 133), "não inclui em sua reflexão um espaço construído para os excluídos dos processos de globalização econômica, em que aqueles pudessem inserir-se dignamente".

Por sorte, os espaços urbanos possuem a mutabilidade como uma das características, e para que possa ocorrer uma mudança no processo de urbanização, é fundamental que ocorra a interferência dos citadinos, tanto enquanto agentes transformadores como também enquanto agentes a serem transformados pelo processo de urbanização, uma vez que quanto maior for o estágio de igualdade, de justiça social, de paz, de democracia, de solidariedade entre os habitantes das cidades, maior será o grau de proteção e materialização do direito à cidade. Nesse sentido, Schonardie (2012) refere que:

A cidade é um espaço coletivo cultural rico e diversificado que pertence a todos os habitantes, ou seja, a todos os cidadãos(ãs) que nela habitam de forma transitória ou permanente e, além disso, deve ser um espaço de realizações de todos os direitos humanos e liberdades fundamentais (SCHONARDIE 2012, p. 259).

A necessidade de mudança no processo de urbanização brasileiro é trazida pela Constituição de 1988, bem como pelo Estatuto da Cidade ao reconhecerem o direito à cidade como direito 
fundamental. Ambos os documentos rompem com a tradição civilista e com a concepção individualista do direito de propriedade imobiliária pregadas desde a década de 1930 ao defender que o direito de propriedade imobiliária urbana é assegurado quando cumprida sua função social. Ao explicar o significado do princípio da função social da propriedade, Mattos (apud Carrera, 2005, p. 41) destaca que tal princípio "funciona como uma espécie de princípio derivado do princípio da dignidade da pessoa humana ditando o modo como deve ser utilizada a propriedade no espaço urbano".

A gestão urbana para o desenvolvimento sustentável é um dos grandes desafios do sistema urbano. As relações sociais, os padrões de distribuição de renda, as interferências tecnológicas e industriais, a qualidade de vida das populações, enfim, as diferentes utopias de sociedade poderão ser enunciadas de acordo com a capacidade dos cidadãos e do Estado em gerir o entorno.

A busca pelo desenvolvimento urbano sustentável representa uma luta política pela reconstrução da cidade e dos espaços urbanos e exige conhecimento sobre a realidade urbana, a fim de que sejam buscadas e implementadas soluções alternativas e sustentáveis para os impactos socioambientais, constantemente gerados pela forma como se deu o processo de urbanização no Brasil. Desta maneira, é imprescindível a reprodução de políticas públicas associadas à sustentabilidade na tentativa de viabilizar a governança do próprio futuro à condição de cidadania.

Ninguém está excluído da missão na busca pela implementação do desenvolvimento sustentável nas cidades, a fim de que essas se tornem mais inclusivas e que as diferenças sejam diminuídas. O futuro da cidade legal e a garantia de qualidade de vida e bem-estar para as gerações presentes e futuras dependem de uma mobilização de todos os citados, já que, é dever conjunto do Estado, sociedade e mercado o alcance do equilíbrio entre o homem, seu espaço e a natureza.

Portanto, para que seja alcançada a tão desejada cidade inclusiva e sustentável é necessário que ocorra uma urgente reformulação nas formas, estruturas e funções da cidade, do ponto de vista econômico, político e cultural, bem como das necessidades sociais inerentes à sociedade urbana. Lefebvre (2001, p. 116-117) destaca, nesse sentido, que o direito à cidade "precisa ser formulado como direto à vida urbana, transformada, renovada".

Em complementação, Carrera (2005, p. 33-34) define que a cidade inclusiva e desejada não é outra, senão aquela "onde se pratica, efetivamente o desenvolvimento, sustentável, com o objetivo constitucional e primordial de se garantir o sustento das gerações presentes e futuras". Assim, uma cidade na qual as desigualdades sociais sejam reduzidas por meio da aplicação dos princípios relacionados à política urbana e à dignidade da pessoa humana, será uma cidade inclusiva e sustentável, na qual os direitos humanos são efetivados. 
A cidade constitui-se, também, como o espaço da experiência coletiva e da manifestação do individual e da experiência coletiva, uma vez que existe nela uma variedade de trocas que colaboram para a sociabilidade. Ainda, a cidade possui uma dimensão explicativa que é uma condição de realização da vida cotidiana que decorre da relação do indivíduo com o espaço urbano, conforme preceitua Ana Fani Alessandri Carlos (2001):

[...] as relações sociais têm sua realização ligada à necessidade de um espaço onde ganha concretude a casa como universo do homem privado; a rua como acessibilidade possível aos espaços públicos, lugar dos encontros, dos percursos [...]. As relações que os indivíduos mantêm com os espaços habitados se exprimem todos os dias nos modos do uso, nas condições mais banais e acidentais, na vida cotidiana. Revela-se como espaço passível de ser sentido, pensado, apropriado e vivido pelo indivíduo por meio do corpo, pois é com todos os sentidos que o habitante usa o espaço, cria/percebe os referenciais, sente os odores dos lugares, dando-lhes sentido, o que significa que o uso envolve o indivíduo e seus sentidos, seu corpo; é por ele que marca sua presença, é por ele que constrói e se apropria do espaço e do mundo do lugar, no modo como usa o espaço e emprega o tempo da vida cotidiana (CARLOS, 2001, p. 34-35).

Nesse sentido, cada sociedade produz o seu próprio espaço, que expressa sua função social, determina os ritmos de vida, os modos de apropriação, os projetos e desejos, uma vez que "as transformações econômico-sociais deixam na cidade marcas e sinais que contam uma história não verbal pontilhada de imagens, de máscaras, que tem como significado o conjunto de valores, usos e hábitos, desejos e crenças que misturam, através do tempo, o cotidiano dos homens" (FERRARA apud PESAVENTO, 1999, p. 15).

Assim, a utilização do espaço unida ao hábito constitui uma imagem perceptiva que se sobrepõe ao projeto urbano e constitui o elemento de manifestação concreta do espaço. O coletivo atribui ao espaço ocupado o seu sentido. Por exemplo, a praça, a rua, o pequeno comércio aproximam os moradores, podendo, além de ser pontos de trocas de mercadorias, possibilitar o encontro, reforçando a sociabilidade. E o mesmo espaço urbano sonhado, desejado, batalhado e/ou imposto é também reformulado, vivido e descaracterizado pelos citadinos, que, por sua vez, requalificam o espaço e the conferem novos sentidos (PESAVENTO, 1999).

A cidade é um meio, as pessoas são o fim, logo, o meio urbano carrega a humanidade dentro de sua concepção. No entanto, assim como a história e a justiça dos direitos humanos, a história do direito à cidade inclusiva, ainda que normatizada, não oferece "uma definição e uma descrição da sociedade justa ou uma prescrição de suas condições de existência. [...]. Os direitos humanos não têm um lugar, um tempo ou ideologia próprios, eles não podem ser atribuídos a nenhuma época ou 
partido específicos" (DOUZINAS, 2009, p.374), uma vez que desperta como produto da luta de classe e do confronto dos diversos poderes sociais organizados e não como atributo humano metafísico.

Ao longo da história a humanidade vivenciou uma intensa luta pela promoção e reconhecimento dos direitos humanos. Nesse sentido, os direitos humanos são o resultado de uma evolução social dos seres humanos, ou seja, uma evolução mental do indivíduo que percorre cada um dos períodos históricos. Atualmente, o direito à cidade encontra-se inserido no rol dos direitos humanos, e tem por objetivo promover a diminuição da desigualdade e discriminação social, por meio da construção de uma ética urbana fundamentada na justiça social e cidadania.

No entanto, apesar de a dimensão histórica dos direitos humanos provir das mais variadas formas de opressão e desrespeito ao ser humano, tais fatores históricos não bastam para garantir a representação simbólico-imaginária e a batalha pela concretização de tais direitos. Tanto é que o direito fundamental à cidade não se constitui como realidade para a maioria dos brasileiros, sendo que "a ausência de condições ideais para a realização dos direitos humanos, a desigualdade social, e a expansão da pobreza tornam ainda mais conflituoso o espaço urbano" (SCHONARDIE, 2014, p. 148).

Nesse sentido, Bobbio (2004) destaca que:

o problema grave do nosso tempo, com relação aos direitos do homem, não era mais o de fundamentá-los, e sim o de protegê-los. [...] Não se trata de saber quais e quantos são esses direitos, [...] mas sim qual é o modo mais seguro de garanti-los para impedir que, apesar de solenes declarações, eles sejam continuamente violados (BOBBIO, 2004, p. 25).

Em uma ideia complementar, Doglas César Lucas (2010) refere que os Estados já não possuem capacidade de garantir, de forma autônoma e soberana, a prevalência dos projetos nacionais sobre a ordem internacional dos acontecimentos econômicos, políticos, culturais, religiosos. A soberania dos Estados já não é suficiente para enfrentar de maneira mais apropriada os problemas que afetam a humanidade como um todo e, especialmente para fomentar uma cultura político-jurídica transacional de direitos humanos.

Assim, o grande desafio que surge é o de efetivar a gestão democrática, condição imperativa para o que se atinja um sistema urbano sustentável, no qual haja uma efetiva redução das desigualdades sociais e promoção dos direitos humanos, o que somente é possível através do exercício da cidadania, uma vez que os próprios indivíduos e o Estado são atores principais na garantia da efetividade das funções sociais da cidade, a fim de que o direito à cidade seja plenamente confirmado como direito humano das gerações presentes e futuras. 
Portanto, o Estado e a comunidade devem, conjuntamente, fiscalizar o espaço público, a fim de que sejam diminuídas as desigualdades sociais, o que se entende ser possível através da gestão democrática da cidade, que, para ser concretizada, necessita a organização da sociedade civil, de modo que possa interferir no processo político em nome das demandas sociais, sendo que tal interferência somente se estabelece por meio do exercício da cidadania (SAULE JÚNIOR, 2007). É preciso que todos os citadinos se reconheçam como autores da própria história, para que seja possível a redução das desigualdades sociais que acometem o meio urbano brasileiro.

Os instrumentos do Estatuto da Cidade, em especial no que se refere à gestão democrática, precisam ser utilizados como forma de concretizar e garantir o direito às cidades sustentáveis, com a efetiva redução das desigualdades sociais, uma vez que a democracia é indispensável para a emancipação dos cidadãos e a efetivação do direito à cidade.

Nesse sentido, é imprescindível que seja formulado um novo marco teórico que se preste para explicar e analisar as dimensões política e social do processo de urbanização, que considere as mudanças político, econômicas e sociais no cenário urbano contemporâneo, bem como que trabalhe com fronteiras menos largas entre o público e o privado. A criação de uma esfera pública efetiva no processo de gestão urbana requer a combinação entre os mecanismos tradicionais da democracia representativa com novos processos e mecanismos que assegurem formas diferenciadas, e efetivas, de participação direta. Em outras palavras, é preciso que as várias formas do conflito social que se encontram na base da produção do espaço urbano encontrem uma arena mais ampla no processo decisório, o que somente é possível pela aplicação da gestão democrática nas cidades.

No entanto, a devida utilização das possibilidades de gestão democrática previstas no Estatuto da Cidade depende da compreensão de seu significado e de seu alcance no contexto da ordem jurídica brasileira. Não é simplesmente por imposição legislativa que tais mudanças irão se concretizar. É preciso que a esfera privada se una à esfera pública, com o intuito de ocasionar uma efetiva reforma nos processos de gestão político-institucional, político-social e políticoadministrativo, para tanto, uma mudança no comportamento dos cidadãos, de forma a efetivar e ampliar as possibilidades reconhecidas é imprescindível.

Nesse sentido, Fernandes (2012) defende que é preciso promover uma reforma paradigmática uma vez que o direito administrativo tradicional não dá conta das novas relações que estão se formando entre Estado e sociedade para a gestão da cidade. Nas palavras do autor:

Há hoje, internacionalmente, toda uma ênfase nas estratégias de parcerias, negociações urbanas e operações interligadas, refletindo toda uma demanda pela reforma e flexibilização do planejamento urbano, especialmente no contexto da competição entre cidades para atração de investimentos, 
inclusive internacionais. Entretanto, as bases jurídicas dessas mudanças ainda são precárias e precisam ser aprimoradas. Ainda não existe, não só no Brasil, mas internacionalmente, uma ordem jurídico-urbanística adequada que dê conta dessas novas relações que estão sendo materializadas nas práticas políticas e urbanísticas. A verdade é que o direito está correndo atrás da realidade, tentando encontrar uma fórmula que concilie as necessidades da flexibilização administrativa com a necessidade da segurança jurídica, da transparência, do controle social e da predominância do interesse público. (FERNANDES, 2012, p. 26)

A realização das funções sociais da cidade, e consequente, do direito à cidade, com a efetiva diminuição das desigualdades sociais, é pouco provável sem movimentos de participação social e sem políticas públicas adequadas. Para que se efetive o direito humano à cidade, é imprescindível a existência de conhecimentos interdisciplinares, planejamento intersetorial e, em especial, o processo de governabilidade democrática, visto que não é possível concretizar o direito à cidade sustentável e inclusiva enquanto não se materializar a obrigação dos cidadãos em colaborar para sua efetivação. Nesse sentido, Douzinas (2009) destaca que o

reconhecimento mútuo dos cidadãos como agentes autodeterminantes decorre da livre participação no processo democrático de tomada de decisões e da sua ampliação da política para outras áreas da vida social. O autodesenvolvimento, por outro lado, é o oposto da opressão: ele requer a ampliação do princípio da igualdade, da tomada de decisão jurídica para um número cada vez maior de áreas da vida social, tais como o local de trabalho, a vida doméstica, o meio ambiente etc., e sua transformação de um princípio formal para um substantivo (DOUZINAS, 2009, p. 294).

Assim, a participação ativa do cidadão na comunidade garante-lhe a proteção estatal, visto que a cidadania se faz mais ativa quando o cidadão participa efetiva e permanentemente na gestão dos negócios públicos e nos interesses gerais da sociedade. Os direitos difusos como não podem ser individualizados em sua titularidade jurídica nem particularizados em seu exercício, passam a compor o núcleo básico de interesses e direitos a serem objeto de cuidados de todos os cidadãos

Nesse sentido, tem-se que os direitos fundamentais da pessoa humana (direitos humanos) são dirigidos a todas as pessoas, independentemente de onde se encontrem, bem como devem proteger a dignidade da pessoa humana em todos os sentidos, uma vez que são caracterizados por serem inalienáveis, imprescritíveis, irrenunciáveis, indivisíveis e universais, e devem ser respeitados.

Conforme preleciona Cenci (2010), o direito à cidade sustentável constitui-se em direito fundamental e como tal, protegido por lei. No entanto, a sua efetivação depende a própria realização humana. Ou seja, assim como a compreensão da realização da cidadania está intrinsecamente relacionada com participação social, a ameaça e a exclusão geradas pelo acesso restrito aos bens 
naturais por parte de muitos, identifica neste momento histórico, a concretização da cidadania está intrinsecamente vinculada ao acesso à cidade inclusiva e ao desenvolvimento sustentável.

Assim, a cidadania será mais efetiva no momento em que os indivíduos tomarem consciência de suas particularidades, e, sobretudo, de sua humanidade comum. Quanto mais se fortaleçam os contatos entre indivíduos que se apresentam nas mesmas necessidades de identificação cultural ora na qualidade de cidadãos do mundo, ora na qualidade de membros da sua comunidade -, mais os homens poderão realizar diálogos para que se reconheçam no outro, somente então, ocorrerá a interculturalidade e a redução das diferenças (LUCAS, 2010).

Por fim, a cidadania é essencial para a concretização dos direitos humanos e do direito à cidade, uma vez que aqueles são os direitos mais relevantes já conquistados, e que este está naquele inserido e que a cidadania é um componente fundamental do desenvolvimento social na busca pela efetivação dos direitos humanos.

\section{CONSIDERAÇÕES FINAIS}

Ao longo da história a humanidade vivenciou uma intensa luta pela promoção e reconhecimento dos direitos humanos. Nesse sentido, os direitos humanos são o resultado de uma evolução social dos seres humanos, ou seja, uma evolução mental do indivíduo que percorre cada um dos períodos históricos. Atualmente, o direito à cidade encontra-se inserido no rol dos direitos humanos, e tem por objetivo promover a diminuição da desigualdade e discriminação social, por meio da construção de uma ética urbana fundamentada na justiça social e cidadania.

O direito à cidade, ao ser considerado como um direito humano, que visa a modificar a realidade urbana mundial, mediante a construção de cidades justas democráticas e sustentáveis, deve ser protegido e garantido aos habitantes da cidade, a fim de que estes tenham sua cidadania garantida. Ao ser compreendido como espaço coletivo culturalmente rico e diversificado, o direito à cidade deve almejar a proteção, em especial, dos grupos vulneráveis que vivem nos espaços urbanos, com o objetivo de se alcançar o pleno exercício do direito à livre autodeterminação e a um padrão de vida adequado.

Atualmente, uma enorme parcela da população que vive nas cidades se encontra em condições de subcidadania, uma vez que se utiliza de espaços, públicos ou privados, invadidos ou que não apresentam qualquer infraestrutura por parte dos órgãos públicos. Assim, vive-se uma realidade de segregação, exclusão e injustiça social, diante da qual surge o Estatuto da Cidade como forma de tentar contornar tal conjuntura e efetivar a cidadania nos espaços urbanos. 
Percebe-se que a ausência do exercício da cidadania expõe toda a fragilidade do ser humano, como indivíduo que renunciou à sua condição de agente capaz de modificar a própria história. Verifica-se, assim, a importância da cidadania para o direito à cidade, uma vez que o direito a vivem em um espaço sadio é constitucionalmente reconhecido.

A fim de apresentar suporte jurídico ao direito à cidade, no Brasil foi promulgado, no ano de 2001, o Estatuto da Cidade, que vem para dar a densidade jurídica necessária aos artigos 182 e 183 da Constituição Federal de 1988. O Estatuto da Cidade representa o suporte jurídico para a realização do planejamento urbano e para a ação dos governos municipais, ao estabelecer as diretrizes fundamentais ao planejamento e para a condução do processo de gestão das cidades.

Posto que a proteção aos direitos fundamentais busca limitar o poder do Estado e de outras instituições, implica o reconhecimento dos indivíduos como sujeitos de direitos, isto é, a possibilidade de serem atores de sua própria história; o Estatuto da Cidade estabelece em seu artigo 2o, inciso ll a diretriz da gestão democrática "por meio da participação da população e de associações representativas dos vários segmentos da comunidade na formulação, execução e acompanhamento de planos, programas e projetos de desenvolvimento urbano".

A gestão democrática da cidade tem base nos preceitos constitucionais de democracia participativa, cidadania, soberania e participação popular. Por ser a democracia caracterizada como o conjunto das garantias institucionais que permitem combinar a unidade da razão instrumental com a diversidade das memórias, a permuta com a liberdade, essa é a forma de vida política que dá maior liberdade ao maior número de pessoas, que protege e reconhece a maior diversidade possível. Já a soberania popular é o eixo central da ideia de democracia, uma vez que é uma ordem política produzida pela ação humana que não pode ser explicada por um Estado específico, já que a realização da democracia transcende o Estado.

A democracia pressupõe que as decisões sejam tomadas pela maioria dos cidadãos, e que, por cidadãos devem ser entendidos todos aqueles, capazes, que compõem a coletividade do Estado, sem qualquer tipo de discriminação, seja por cor, raça, sexo. O Estado de direito oferece especial atenção ao cidadão, seja quanto aos direitos fundamentais que devem ser garantidos e protegidos, seja no campo do uso da força por parte do Estado, que passa a ser regulada por normas gerais, e não mais caso a caso. Sabe-se que os direitos humanos não existem em um sistema que não seja o democrático; direitos humanos e Estado democrático são inerentes um ao outro, em sua essência conceitual.

Assim, a participação ativa do cidadão na comunidade garante-lhe a proteção estatal. Nesse sentido, tem-se que os direitos fundamentais da pessoa humana são dirigidos a todas as pessoas, independentemente de onde se encontrem, bem como devem proteger a dignidade da pessoa 
humana em todos os sentidos, uma vez que são caracterizados por serem inalienáveis, imprescritíveis, irrenunciáveis, indivisíveis e universais, e devem ser respeitados.

Nesta senda, implantar uma gestão democrática nas cidades, com participação dos cidadãos na tomada de decisões é fator preponderante e imprescindível na luta pela efetivação das funções sociais da cidade, visto que por meio de tal instituto se entende possível gerar melhores condições de vida aos citadinos, respeitando os princípios da dignidade humana e da cidadania, entendida como a garantia dos direitos e deveres de todos os cidadãos independente das condições em que se encontrem, posto que, para que sejam efetivados os direitos humanos, é fundamental que a discriminação e as desigualdades sociais sejam reduzidas.

Ou seja, entende-se que, por meio da gestão democrática das cidades, torna-se possível a avaliação de interesses coletivos com vistas a reduzir a desigualdade social, tornando as cidades o local ideal para que os direitos humanos sejam efetivados, uma vez que é nos espaços urbanos que ocorre a gerência da vida da sociedade. Assim, a gestão democrática deve buscar um desenvolvimento que vise combater as desigualdades, o uso irresponsável dos recursos naturais, ou seja, o desenvolvimento sustentável por meio do planejamento urbano mais humano, menos excludente, objetivando a vida digna com qualidade para a maior parte da população.

Para tanto, devem ser utilizados instrumentos que possibilitem a democracia participativa nas decisões políticas a serem tomadas, a fim de que determinados grupos sociais específicos não sejam privilegiados em relação aos demais, sob a consequência de, caso assim não o seja, se aumentar ainda mais as desigualdades e se estar infringir os direitos humanos e, consequentemente, se discriminar grupos sociais economicamente menos favorecidos, que já vivem em situações de vulnerabilidade social.

Percebe-se que a democracia não se restringe somente ao zelo pela legalidade, mas também pela proteção aos direitos humanos. Nesse sentido, é possível assegurar que a igualdade política é condição para a democracia, mas esta não significa tão somente a atribuição de direitos iguais; implica compensar as desigualdades, tarefa do Estado democrático. Portanto, o estado e a comunidade devem, conjuntamente, fiscalizar o espaço público, a fim de que sejam diminuídas as desigualdades. No entanto, governar democraticamente as cidades certamente é um grande desafio para a humanidade, uma vez que a governança democrática pressupõe que sejam respeitados os direitos dos habitantes que vivem em territórios com grandes diferenças econômicas, políticas, culturais, ambientais e sociais.

Para que seja concretizada, a gestão democrática da cidade necessita que a sociedade civil se organize, de modo que possa interferir no processo político em nome das demandas sociais, tal ingerência se estabelece por meio do exercício da cidadania. Sabe-se que o cidadão constitui 
elemento essencial para a democracia, uma vez que é ele quem escolhe os representantes legais que irão formular as leis, em nome deste cidadão. Assim, quanto maior o número de atores (cidadãos) participando da tomada das decisões políticas, mais democrática será a sociedade.

É preciso que todos os citadinos sejam reconhecidos como portadores de direitos universais. Este comportamento decorre de um espírito democrático, uma vez que estabelece além de um reconhecimento em si, um reconhecimento no outro, com suas diferenças e semelhanças, assim como preceituam os direitos universais do homem. Cada indivíduo deve ser protegido com suas próprias características, bem como estas devem ser respeitadas pelo restante da coletividade, uma vez que o Estado democrático pressupõe o respeito e aceitação às diferenças, e que a proteção à identidade também é um dos objetivos da democracia. Nesse sentido, o direito à cidade surge como possibilidade de que a segregação social seja reduzida, e que a qualidade de vida dos indivíduos que habitam tais espaços seja alavancada, a fim de que ocorra uma mudança na própria realidade urbanística.

Pelo exposto, é possível afirmar que a hipótese proposta foi confirmada a partir da constatação de que o direito à cidade busca a proteção dos cidadãos, que apesar de suas diferenças, devem ser reconhecidos como portadores de direitos humanos.

\section{REFERÊNCIAS}

BOBBIO, Norberto. A era dos Direitos. Tradução: Carlos Nelson Coutinho. Rio de Janeiro: Elsevier, 2004.

- Teoria geral da política: a filosofia política e a lição dos clássicos. Organizado por Michelangelo Bovero. Tradução de Daniela B. Versiani. Título original: Teoria Generale Della Política. Rio de Janeiro: Campus, 2000

Dicionário de Política. Brasília, DF: Editora Universidade de Brasília, 2000.

BRASIL. Constituição da República Federativa do Brasil de 1988. Disponível em: <http://www.planalto.gov.br/ccivil_03/constituicao/constituicao.htm> Acesso em: 30.set.2015.

Lei no 10.257/2001. Disponível em < http://www.planalto.gov.br/ccivil_ 03/leis/LEIS_2001/L10257.htm>. Acesso em: 03 set. 2015b. 
Ministério das Cidades. Política Nacional de Habitação. Cadernos do MCidades Habitação. Acesso em 20 abr.2015

CALDEIRA, Teresa Pires do Rio. Enclaves fortificados: a nova segregação urbana. Novos Estudos CEBRAP, V. 47, p. 155-76, 1997. Disponível em < http://www.fau.usp.br/cursos/graduacao/arq_urbanismo/disciplinas/aup0278/2014/2014.1_Biblio grafia_Complementar_Geral/Texto_02.pdf>. Acesso em 10.set.2015.

CARLOS, Ana Fani Alessandri. Espaço-Tempo na Metrópole. São Paulo: Contexto, 2001.

CARRERA, Francisco. Cidade Sustentável: utopia ou realidade?. Rio de Janeiro: Lumen Juris, 2005.

CENCI, Daniel Rubens. Conflitos socioambientais urbano-metropolitanos: cidadania, sustentabilidade e gestão no contexto da RMC - Região Metropolitana de Curitiba. Curitiba: Universidade Federal do Paraná, 2010. 267 f. Tese de Doutorado em Meio Ambiente e Desenvolvimento. Linha de Pesquisa: Urbanização, Cidade e Ambiente Urbano.

CORBUSIER, Le. Planejamento Urbano. 3a ed. São Paulo: Perspectiva, 2004.

COUTINHO, Carlos Nelson. Notas sobre cidadania e modernidade. Praia Vermelha: estudos de Política e Teoria Social. Rio de Janeiro, v. 1, n.1, p. 145, 165, 1. sem. 1997.

A democracia como valor universal. Rio de Janeiro: Ed. Salamandra, 1984.

DALLARI, Adilson; FERRAZ, Sérgio. (Coords). Estatuto da Cidade: comentários à Lei Federal 10.257/2001. São Paulo: Malheiros Editores Ltda, 2003.

DEL'OLMO, Elisa Ceriolli. Meio Ambiente Ecologicamente Equilibrado: direito e dever do cidadão. In: SANTOS, André Leonardo Copetti; DEL'OMO, Florisbal de Souza (Orgs.). Diálogo e Entendimento: direito e multiculturalismo e cidadania e novas formas de solução de conflitos.Rio de Janeiro: Forense, 2009, p. 223 - 233.

DIAS, Daniella Maria dos Santos. Planejamento e desenvolvimento urbano no sistema jurídico brasileiro: óbices e desafios. Curitiba: Juruá. 2012. 
DOUZINAS, Costas. O Fim dos Direitos Humanos. São Leopoldo: Unisinos, 2009.

FERNANDES, Edésio. Um novo Estatuto para as cidades brasileiras. In: OSORIO, Letícia Marques. (Org.). Estatuto da Cidade e Reforma Urbana: novas perspectivas para as cidades brasileiras. Porto Alegre: Sergio Antonio Fabris Editor, 2002. p. 07-13.

. Impacto socioambiental em áreas urbanas sob a perspectiva jurídica. In: MENDONÇA, Francisco. (Org.). Impactos Socioambientais Urbanos. Curitiba: Ed. UFPR, 2004. p. 99 - 127.

. Direito e gestão na construção da cidade democrática no Brasil. Oculum Ensaios, n. 4, 2012.

Disponível em: <http://periodicos.puccampinas.edu.br/seer/index.php/oculum/article/view/783/763>. Acesso em 05.nov.2015.

FREITAG, Barbara. Teoria das Cidades. Campinas: Papirus. 2013.

FREITAS, José Carlos de, Bens Públicos de loteamentos e sua proteção especial, Revista de Direito Imobiliário no 46 - IRIB - janeiro-junho de 1999, São Paulo, ed., RT.

GOMES, Paulo César da Costa. A Condição Urbana: ensaios de geopolítica da cidade. 4ạ ed. Rio de Janeiro: Bertrand Brasil, 2012.

GUIMARAENS. Maria Etelvina B. Instrumentos de Garantia da Função Social da Propriedade Urbana: parcelamento e edificação compulsórios, IPTU progressivo no tempo e desapropriação para fins de reforma urbana. In: Estatuto da Cidade e Reforma Urbana: novas perspectivas para as cidades brasileiras. Porto Alegre: Sergio Antonio Fabris Editor, 2002. p. 121-136.

KEITEL, Liane; PEREIRA, Reginaldo; BERTICELLI, Ireno Antônio. Paradígmas emergentes, conhecimento e meio ambiente. Ensaio Pesquisa em Educação em Ciências, v. 14, n. 1, p. 131, 2012. Disponível em < http://www.portal.fae.ufmg.br/seer/index.php/ensaio/article/view/279/799>. Acesso em 07.dez.2015.

KRELL, Andréas J. O desenvolvimento sustentável às avessas na praia de Maceió: a liberação de espigões pelo novo Código de Urbanismo e Edificações. Maceió: EDUFAL, 2008. 
LEFEBVRE, Henri. O direito à cidade. São Paulo: Centauro, 2001.

LEFF, Enrique. Saber Ambiental: sustentabilidade, racionalidade, complexidade, poder. 3 ed. Petrópolis: Vozes, 2004.

LINS JÚNIOR, G. S. Direito à habitação adequada: o desafio da efetividade e o discurso no Judiciário.In: SILVA, Artur Stamford da (Org.). O judiciário e o discurso dos direitos humanos: o judiciário e o discurso dos direitos humanos. Recife: EDUFPE, 2011.

LUCAS, Doglas Cesar. Direitos Humanos e Interculturalidade: um diálogo entre a igualdade e a diferença. ljuí: Unijuí, 2010.

MATTOS, Liana Portilho. (Org.). Estatuto da Cidade Comentado. Belo Horizonte: Mandamentos, 2002.

MEIRELLES, Helly Lopes. Direito Municipal Brasileiro. 6. ed. São Paulo: Malheiros, 1993.

MENDONÇA, Francisco. S.A.U - Sistema Ambiental Urbano: uma abordagem dos problemas socioambientais da cidade. In: MENDONÇA, Francisco. (Org.). Impactos

Socioambientais Urbanos. Curitiba: Ed. UFPR, 2004. p. 185 - 207.

NALINI, José Renato. Os direitos que a cidade esqueceu. São Paulo: Revista dos Tribunais, 2011.

OLIVEIRA, Régis Fernandes de. Comentários ao Estatuto da Cidade. São Paulo: Revista dos Tribunais, 2002.

OSÓRIO, Letícia, SAULE JUNIOR, Nelson. Direito à moradia no Brasil. Relatório Nacional do Projeto de Relatores Nacionais do DhESC. São Paulo, 2003. Disponível em <http://www.fna.org.br/site/uploads/noticias/arquivos/Direito_a_Moradia_no_Brasil. pdf>. Acesso em 2.abr.2015.

PESAVENTO, Sandra Jatahy. O imaginário da cidade: visões literárias do urbano - Paris, Rio de Janeiro, Porto Alegre. Porto Alegre: Editora da Universidade/UFRGS, 1999. 
ROLNIK, Raquel. O que é cidade. São Paulo: Brasiliense, 1995.

Democracia no fio da navalha: limites e possibilidades para a implementação de uma agenda de reforma urbana no Brasil. Revista Brasileira de Estudos Urbanos e Regionais, v. 11, n. 2, p. 31-50, 2011.

SARLET, Ingo. O direito fundamental à moradia aos vinte anos da Constituição Federal de 1988: notas a respeito da evoluçãoem matéria jurisprudencial, com destaque para a atuaçãodo supremo tribunal federal. Revista Brasileira de Estudos Constitucionais - RBEC, Ano 2, n. 8, outubro/dezembro de 2008, p. 55-92.

SAULE JÚNIOR, Nelson. Direito Urbanístico: vias jurídicas das políticas urbanas, Porto Alegre: Sergio Antonio Fabris, 2007.

Novas perspectivas do direito urbanístico brasileiro. Ordenamento constitucional da política urbana. Aplicação e eficácia do plano diretor. Rio Grande do Sul: Sergio Antonio Fabril Editor, 1997.

\section{SAULE JUNIOR, Nelson; Uzzo, Karina. A Trajetória da Reforma Urbana no}

Brasil. Disponível em: <http://scholar.googleusercontent.com/scholar?q=cache: wFDoHD_cjQMJ:scholar.google.com/\&hl=pt-PT\&as_sdt=0,5>. Acesso em 25.out.2015.

SCHONARDIE, Elenise Felzke. Direito à Cidade e Favelização: as interfaces da desigualdade social e do direito fundamental. In: BEDIN, Gilmar Antonio. (Org.). Cidadania, Direitos Humanos e Equidade. ljuí: Ed. Unijuí, 2012. p. 251-267.

O fenômeno urbano e o direito à cidade: locus de efetivação dos direitos humanos. In: CENCI, Daniel Rubens; SCHONARDIE, Elenise Felzke. (Org.). Direitos humanos, meio ambiente e novos direitos. ljui: Ed. Unijui, 2014. p. 135-158.

SECRETARIA NACIONAL DE TRANSPORTE E MOBILIDADE URBANA DO MINISTÉRIO DAS CIDADES (SEMOB). Estatuto da mobilidade urbana: texto básico de fundamentação do anteprojeto de lei Documento para discussão. Brasília (mimeo), 2005. 
STRECK, Lenio Luiz; BOLZAN DE MORAIS, José Luis. Ciência Política e teoria geral do estado. Porto Alegre: Livraria do Advogado, 2001.

TOURAINE, Alain. O que é a democracia? Tradução de Guilherme João de Freitas Teixeira. Petrópolis, RJ: Vozes, 1996.

Trabalho enviado em 27 de novembro de 2018

Aceito em 30 de setembro de 2019 